Technological University Dublin

DƯBLIN

ARROW@TU Dublin

2018-8

\title{
The Influence of Soft Contact Lens Materials on the Central, Para- Central and Peripheral Corneal Endothelium
}

\author{
Aoife Lloyd McKernan \\ Technological University Dublin, aoifemarie.lloyd@tudublin.ie \\ Luisa Simo Mannion \\ Plymouth University \\ Veronica O'Dwyer \\ Technological University Dublin, veronica.odwyer@tudublin.ie
}

Follow this and additional works at: https://arrow.tudublin.ie/scschphyot

Part of the Physics Commons

\section{Recommended Citation}

Lloyd McKernan, A., Simo Mannion, L. \& O’Dwyer, V. (2015). The influence of soft contact lens materials on the central, para-central and peripheral corneal endothelium. Contact Lens \& Anterior Eye, vol. 41, S. 1. doi:10.1016/j.clae.2018.04.080

This Conference Paper is brought to you for free and open access by the School of Physics \& Clinical \& Optometric Science at ARROW@TU Dublin. It has been accepted for inclusion in Other Resources by an authorized administrator of ARROW@TU Dublin. For more information, please contact arrow.admin@tudublin.ie, aisling.coyne@tudublin.ie,gerard.connolly@tudublin.ie.

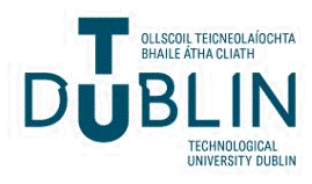




\section{The influence of soft contact lens materials on the central, para-central and peripheral corneal endothelium}

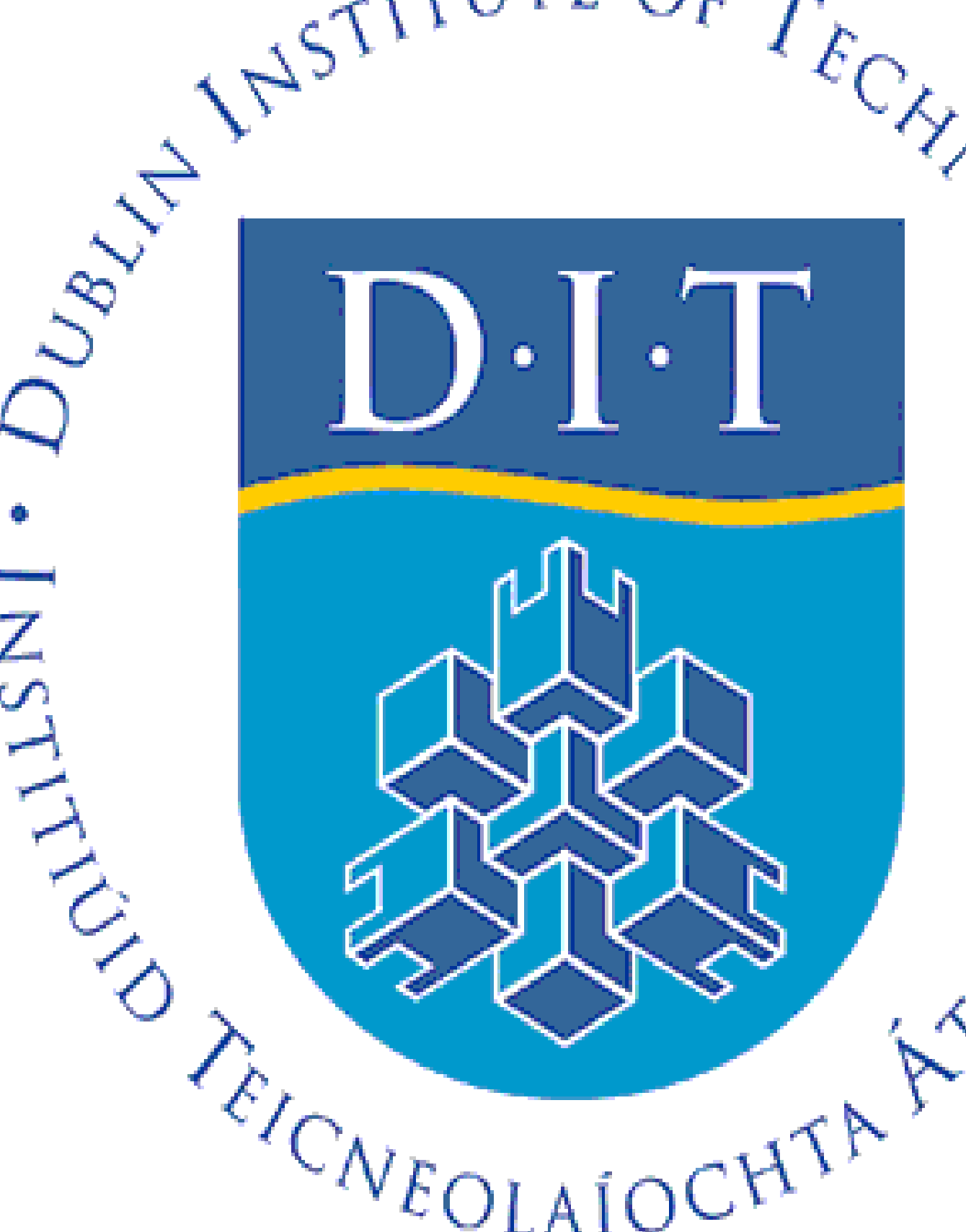

\section{ABSTRACT}

PURPOSE: To examine the influence of a variety of soft contact lens $(\mathrm{SCL})$ materials on the cornea cessation of SCL wear. METHODS: Corneal endothelial cells were (Nidek, Japan). Full-time SCL wearers ( $n=31$ eyes) were compared to a non-contact lens (NCL) control group $(n=28$ eyes) of a similar age (SCL: $20.82 \pm$ 1.69 years, NCL: $21.14 \pm 2.85$ years, $p=0.58$ ) Parameters analysed were endothelial cell density
$\left(\mathrm{ECD} ;\right.$ cell/mm $/ \mathrm{mm}^{2}$, mean cell area (MCA: $\left.\mu^{2}\right)$, $\left(\mathrm{ECD} ; \mathrm{cell} / \mathrm{mm}^{2}\right)$, mean cell area (MCA; $\left.\mu^{2}\right)$,
coefficient of variation (COV) and hexagonality $(\%)$.

RESULTS: Prior to SCL cessation, two-way ANOVA testing showed significant differences between silicone hydrogel (SIH) SCL materials for the COV a 0 , with generation $2 \mathrm{SiH}$ (G2SiH) wearers showing (2) generation $3 \mathrm{SIH}$ (GSSH) wearers $(24.50 \pm 3.73, \mathrm{p}$ significantly lower in the NCL group $(25.63 \pm 2.79)$ compared to the hydrogel group $(29.92+6.22 .79=$ 0.02 ). The MCA in the inferior periphery was als significantly higher in the NCL group (346.92 36.75 ) compared to the hydrogel group (314.92 $16.57, p=0.02$ )

Following 14 days $\mathrm{SCL}$ cessation, no statistically significant differences in stability of endothel parameters were detected between NCL and SCL material groups (all $p$ values $>0.05$ )

CONCLUSION: SCL wear has an effect on paracentral and peripheral corneal endothelia measurements in SCL wearers compared to NCL wearers; with largest significant differences seen two weeks SCL cessation, there were no significan two weeks SCL cessation, there were no significan measurements, regardless of which $\mathrm{SCL}$ material was worn.

\section{BACKGROUND}

Corneal hypoxia due to over-wear of low oxygen transmissibility (DK/t) SCLs results in endothelial polymegathism and corneal thinning ${ }^{1}$. High $\mathrm{DK} / \mathrm{t} \mathrm{SiH}$ materials are reported to have negligible effects on the

Hypothesis: endothelial parameters would show greater variation in a full-time low DK/t hydrogel SCL wearing group compared to a high $\mathrm{DK} / \mathrm{t} \mathrm{SiH}$ wearing group or NCL control group.

Refitting previous low DK/t CL wearers with higher DK/t both the resolution of hypoxia and due to a mechanical reorganisation of the corneal endothelium following resolution of oedema cornduced increased cornea study was examined over a two week period following cessation of SCL wear. This time period was chosen as is the recommended SCL cessation time prior to corne refractive surgery 3 and it has been previously demonstrated ${ }^{4}$ that the resolution of corneal and curvature and

Hypothesis: it was expected that endothelial cornea parameters in full time hydrogel $\mathrm{SCL}$ wearers would be more unstable after two weeks SCL wea

Figure 1: Corneal endothelial data captured by the

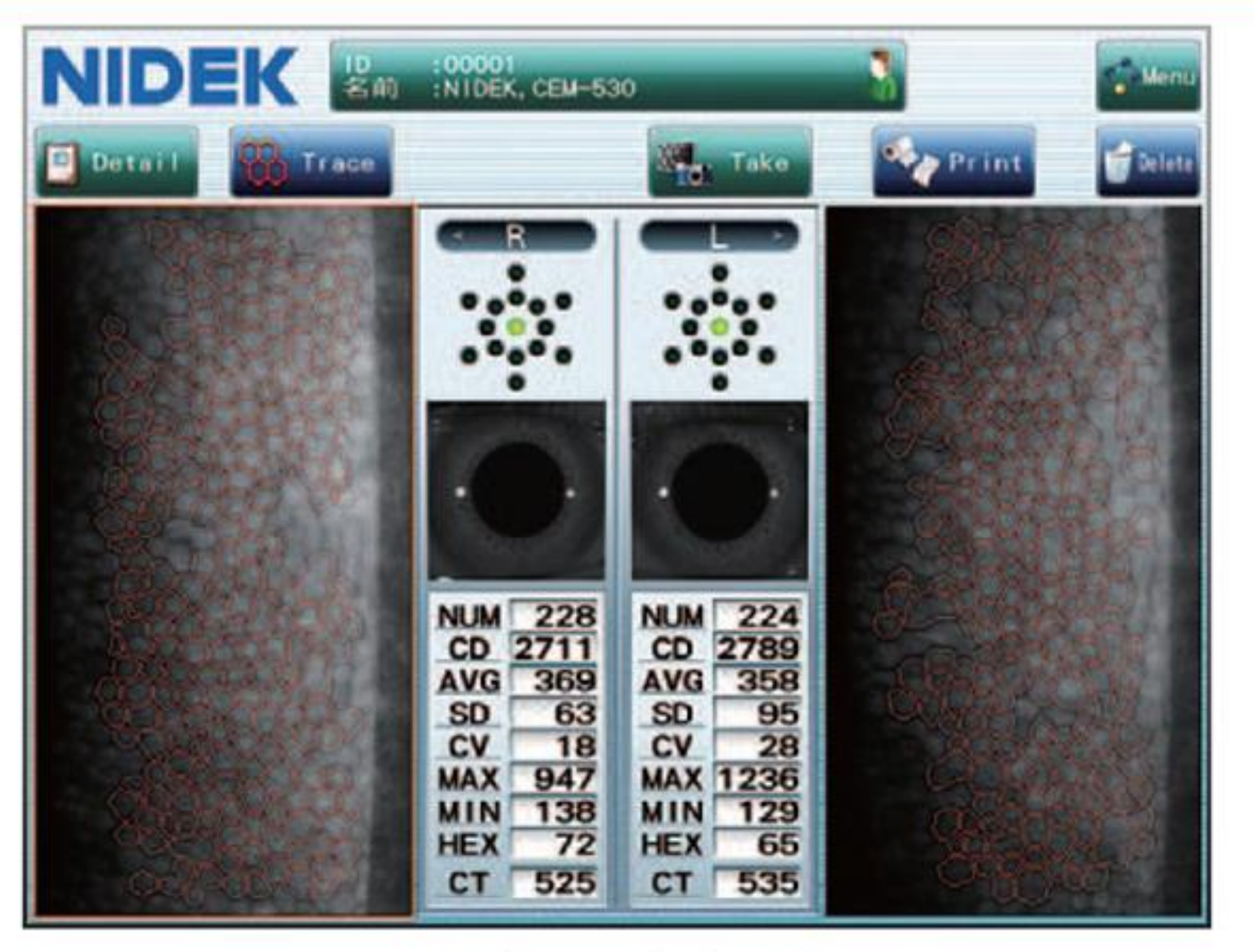

\section{METHODS}

Inclusion criteria

Myopic prescriptions with low astigmatism $<-2.00$ DC). No systemic or ocular disease.

SCL group: Full-time SCL wear (> 5 days per week for at least one year).

NCL group: no history of $\mathrm{CL}$ wear in the year prior to enrolment.

$>$ Data collection

Visits. baselne (SCL group: immediately following SCL removal), following SCL cessation on day 1,2 , \& 14. NCL control subjects were asked to attend the clinic at he same time intervals. Appointments were scheduled at the same time of day ( \pm 2 hours) to limit the possible influence of diurnal variation.

Endothelial specular microscopy: 7 areas of the endothelium were analysed: centrally, paracentrally ( $0.6 \mathrm{~mm}$ from centre) at $0^{\circ}, 90^{\circ}, 180^{\circ}, 270^{\circ}$ and the superior and inferior periphery $(3.7 \mathrm{~mm}$ from centre) (Figure 1 and 2).

\section{Statistical analysis}

SPSS 22 was used for statistical analysis. Normality for continuous data were assessed using the Shapiro-Wilks method. Two-way ANOVA parametric testing was used for comparisons of groups. $\mathrm{P}<0.05$ was considered statistically significant.

Figure 2: Corneal points captured by the CEM-530
specular microscope

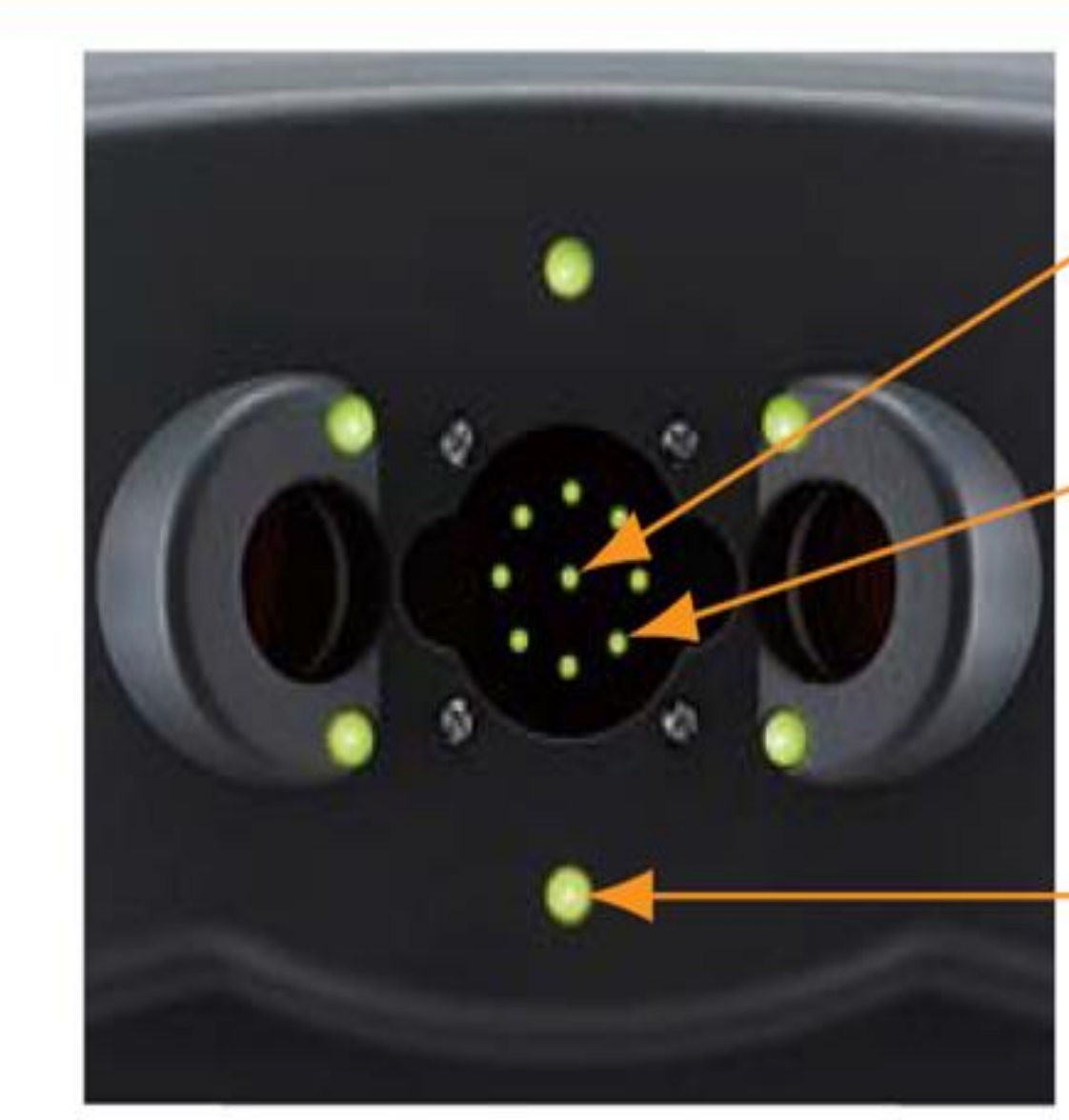

Simulated image of 15 fixation lights*

Central 1 poin

Paracentral 8 points $\left(5^{\circ}\right.$ visual angle)

Peripheral 6 points ( $27^{\circ}$ visual angle)

* Only one selected fixation light is on.

\section{RESULTS}

Two-way ANOVA testing demonstrated no significant effect of SCL material on centra endothelial parameters of $\operatorname{ECD}(p=0.36)$, COV $(p=0.20)$, hexagonality $(p=0.44)$ or MCA $(p=$ 0.88 ) (Figures 3, 4, 5 and 6 ).

Two-way ANOVA and post-hoc Scheffe testing revealed that SCL material had a significant effect on the COV paracentrally at $0^{\circ}$, with G2SiH wearers showing increased COV compared to $\mathrm{G} 3 \mathrm{SiH}$ wearers. The $\mathrm{COV}$ at the superior peripheral location was significantly lower in the NCL compared to the hydrogel SCL group. The MCA in the inferior periphery was significantly higher in the NCL group compared to the hydrogel SCL group (Table 1).

The influence of SCL material worn on the stability of endothelial parameters following 2 weeks SCL cessation was analysed. No significant differences between the SCL material and NCL wearers were found (Two-way ANOVA: all p-values $>0.05$ ).
RESULTS

Figure 3: Endothelial cell density analysed for the SCL materia

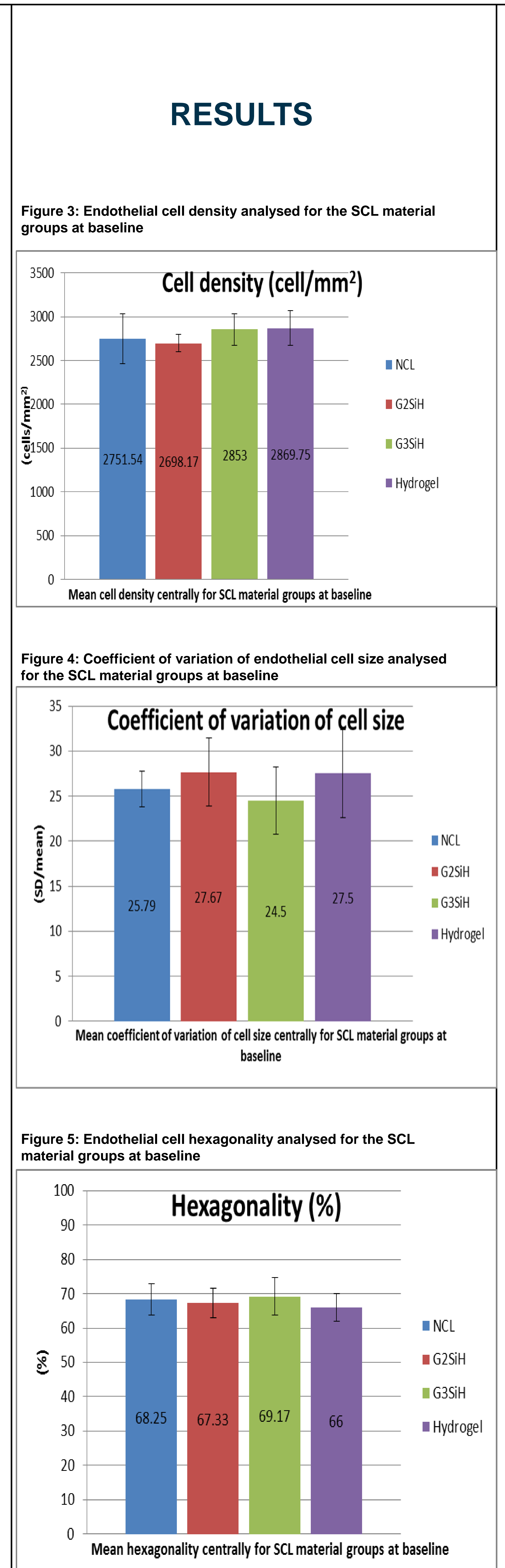

Figure 4: Coefficient of variation of endothelial cell size analysed
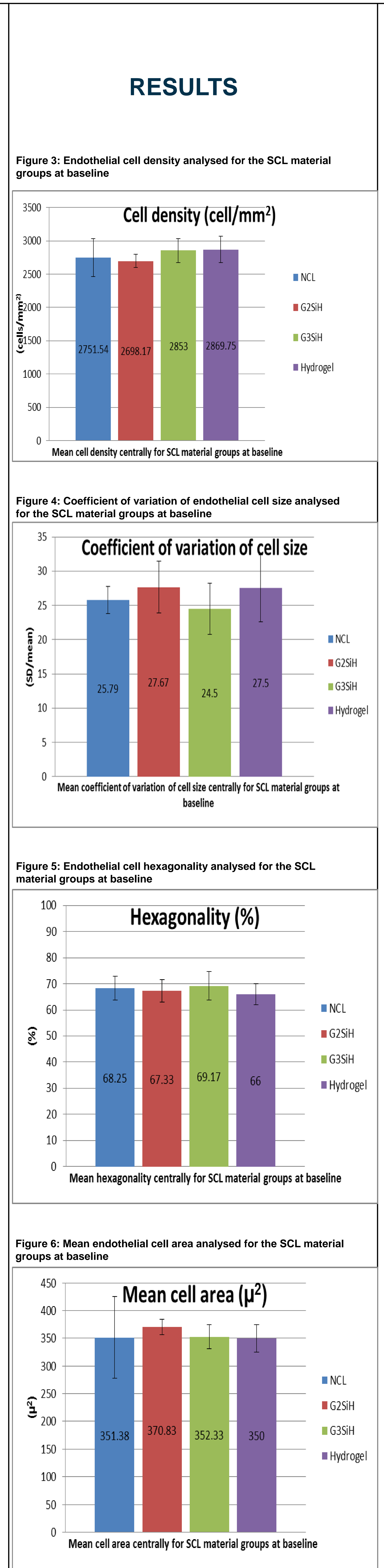

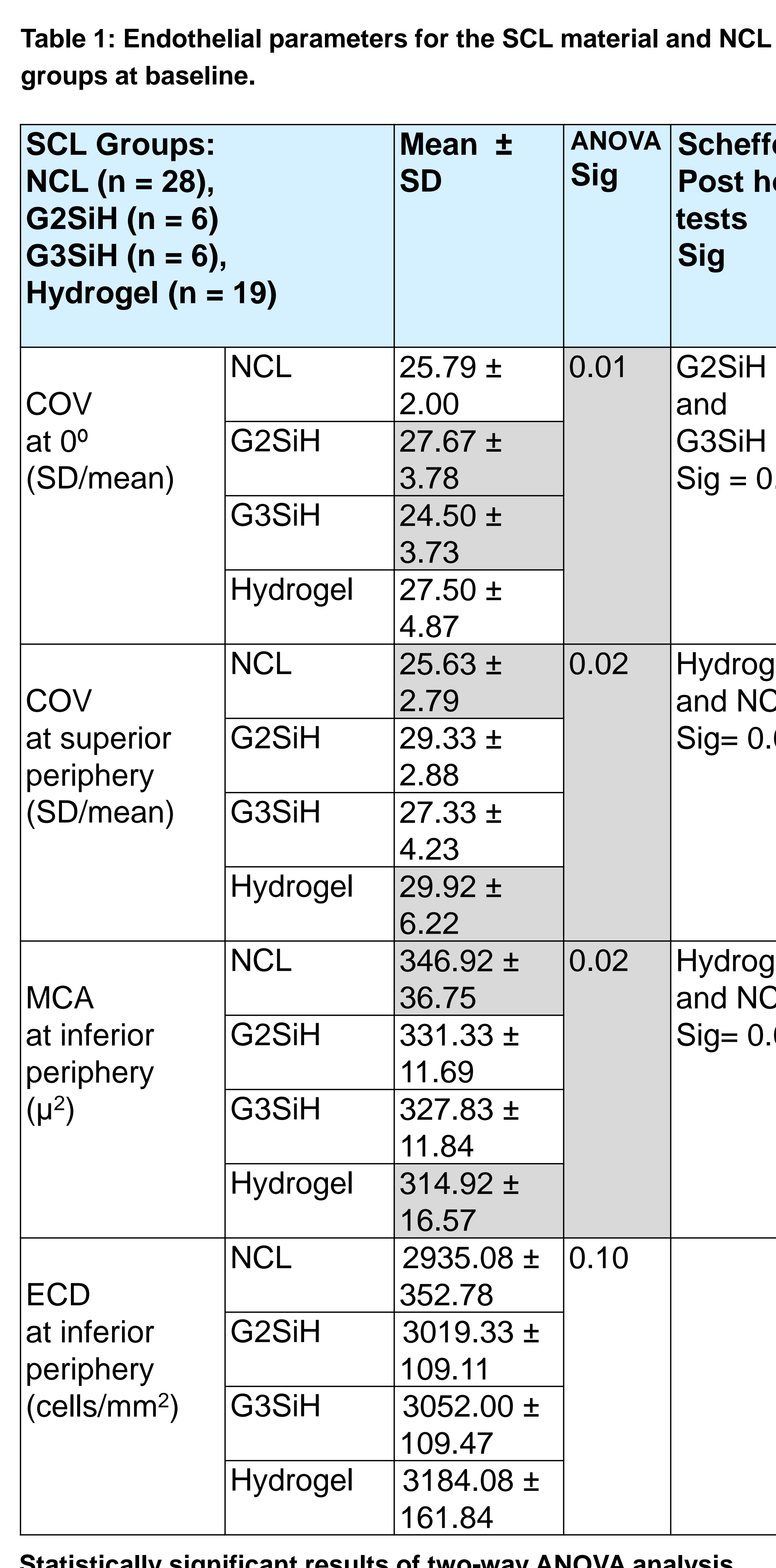

\section{CONCLUSIONS} significant effect on the central endothelial parameters compared to the NCL control group. However, SCL wear had a significant effect on peripheral corneal endothelial measurements in largest significant differences seen between NCL and hydrogel SCL groups.

Results of this study are in agreement with those of Amann et al. (2003) who found increased eripher ECD in SCL who found increased $N C L$ wearers ${ }^{5}$. Amann et al. proposed this was due to a redistribution of endothelial cells towards the periphery in SCL wear. However, we found a significantly reduced MCA in SCL wearers compared to NCL wearers. This reduced MCA would also account for the higher density of cells in the periphery.

Following two weeks SCL cessation, there was no significant differences in the stability of all endothelial measurements, regardess of which $\mathrm{SCL}$ material was worn prior to $\mathrm{SCL}$ cessation.

References:

1. Böhnke, M. \& Masters, B. R. 1999. Confocal microscopy of 2. Doughty, M., Aakre, B., Ystenaes, A. \& Svarverud, E. 2005. continuous wear of silicone hydrogel (lotrafilicon A) contact
lenses after daily hydrogel lens wear. Optometry and Vision

FDA USA. 2014. Medical devices. Products and medical procedures. Surgery and life support devices. Services (ed.)
Page updated $6 / 9 / 2014$ ed. Silver Springs, MD 4. Lloyd McKernan, A, O'Dwyer V, \& Simo Mannion, L. 2014. The Anterior Eye 37. 131-37. 5. Amann, J., Holley, G., Lee, S. \& Edelhauser, H. 2003.
increased endothelial cell density in the paracentral and peripheral regions of the human 